\title{
Short communication: Na-Lauroyl-L-arginine ethylester monohydrochloride reduces bacterial growth in pasteurized milk
}

\author{
N. H. Woodcock, B. H. Hammond, R. D. Ralyea, and K. J. Boor ${ }^{1}$ \\ Milk Quality Improvement Program, Department of Food Science, Cornell University, Ithaca, NY 14853
}

\begin{abstract}
Effective strategies for extending fluid milk product shelf-life by controlling bacterial growth are of economic interest to the dairy industry. To that end, the effects of addition of L-arginine, No-lauroyl ethylester monohydrochloride (LAE) on bacterial numbers in fluid milk products were measured. Specifically, LAE was added $(125,170$, or $200 \mathrm{mg} / \mathrm{L})$ to conventionally homogenized and pasteurized $3.25 \%$ fat chocolate or unflavored milk products. The treated milks and corresponding untreated controls were held at $6^{\circ} \mathrm{C}$ and plated on standard plate count agar within $24 \mathrm{~h}$ of processing and again at $7,14,17$, and $21 \mathrm{~d}$ of storage. Bacterial counts in all unflavored milk samples treated with LAE remained below the Pasteurized Milk Ordinance limit for grade A pasteurized fluid milk of $4.3 \mathrm{log} \mathrm{cfu} /$ $\mathrm{mL}$ for the entire $21 \mathrm{~d}$. Bacterial counts in unflavored samples containing 170 and $200 \mathrm{mg} / \mathrm{L}$ of LAE were significantly lower than those in the untreated unflavored milk at d 17 and 21 postprocessing. Specifically, bacterial counts in the milk treated with $200 \mathrm{mg} / \mathrm{L}$ of LAE were $5.77 \log \mathrm{cfu} / \mathrm{mL}$ lower than in untreated milk at $21 \mathrm{~d}$ postprocessing. Bacterial counts in chocolate milk treated with $200 \mathrm{mg} / \mathrm{L}$ of LAE were significantly lower than those in the untreated chocolate milk at $\mathrm{d}$ 14,17 , and 21 . In chocolate milk treated with $200 \mathrm{mg} / \mathrm{L}$ of LAE, bacterial counts were $0.9 \log \mathrm{cfu} / \mathrm{mL}$ lower than in the untreated milk at $21 \mathrm{~d}$ postprocessing. Our results show that addition of LAE to milk can reduce bacterial growth. Addition of LAE is more effective at controlling bacterial growth in unflavored milk than in chocolate milk.
\end{abstract}

Key words: milk, lauric arginate, shelf life

In recent years, the dairy industry has made strides in improving the quality of commercial fluid milk products (Carey et al., 2005). However, the highly competitive nature of the overall US beverage industry (IDFA, 2007) underscores the need for the dairy industry to

Received February 20, 2009.

Accepted May 11, 2009.

${ }^{1}$ Corresponding author: kjb4@cornell.edu employ innovative methods to ensure retention and possible growth of the fluid milk market share. Specifically, to compete with the rapidly expanding market share enjoyed by such products as shelf-stable bottled water and fruit juice-based beverages (US Census Bureau, 2008), fluid milk processors are striving to further improve product quality and extend shelf life. The most important factor limiting the shelf life of conventionally pasteurized fluid milk is bacterial growth. We hypothesized that use of a "generally recognized as safe" (GRAS) antimicrobial in fluid milk might provide an effective means of extending pasteurized product shelf life by controlling bacterial growth.

L-Arginine, No-lauroyl ethylester monohydrochloride (LAE) is a novel antimicrobial substance derived from lauric acid and arginine. It has been demonstrated as an effective antimicrobial against a variety of microbes. Rodriguez et al. (2004) examined the effect of LAE on Salmonella typhimurium and Staphylococcus aureus. In combination, transmission electron microscopy, fluorescence microscopy, flow cytometry, and ion-flux tests showed that LAE disrupts the structure of the cell membrane and consequently, membrane potential, which results in bacterial cell death. Specifically, the compound disrupts the lipid bilayer in the bacterial membrane, thereby interrupting metabolic processes and inhibiting cellular proliferation (Bakal and Diaz, 2005). Animal toxicological studies (Ruckman et al., 2004) showed that LAE has low acute toxicity, with systemic No Observable Adverse Effect Levels (NOAEL) established at 15,000 $\mathrm{mg} / \mathrm{L}$. In addition, mammalian metabolic studies have shown that LAE is metabolized into the amino acid arginine, which is ultimately broken down into $\mathrm{CO}_{2}$ and urea (Ruckman et al., 2004). In 2005, the FDA granted GRAS status to LAE for use as an antimicrobial in more than 20 foods, including meat and poultry products. Research by Luchansky et al. (2005) showed that Listeria monocytogenes populations inoculated onto the surface of ready-to-eat ham were reduced $2.9,4.6$, or $5.12 \log \mathrm{cfu} / \mathrm{mL}$ when the surfaces had been treated with 4,6 , or $8 \mathrm{~mL}$ of a $5 \%$ LAE solution, respectively. L-Arginine, No-lauroyl ethylester monohydrochloride is not currently approved for use in dairy products (USDA, 2008c). 


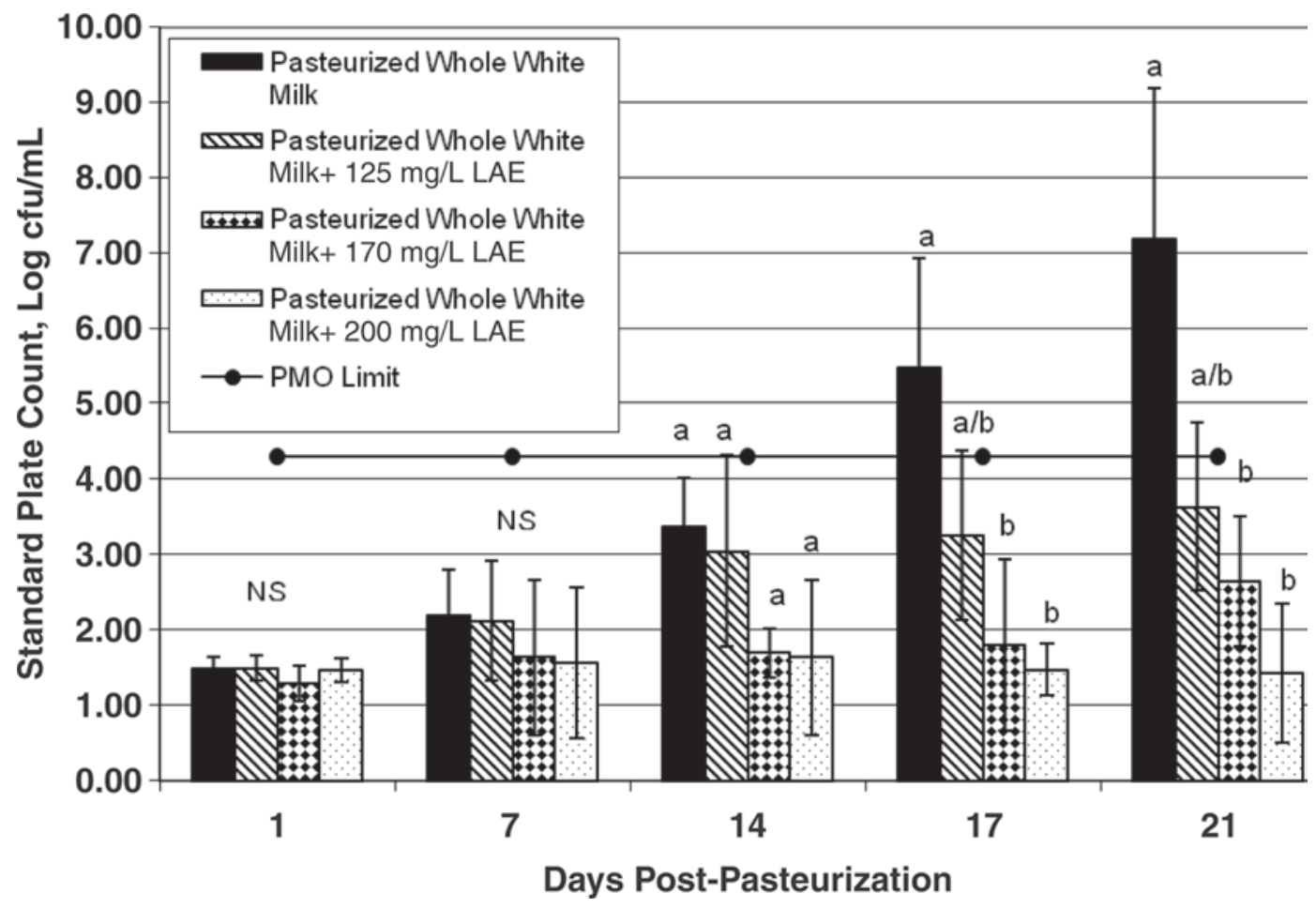

Figure 1. Mean standard plate count for pasteurized unflavored milk treated with L-arginine, No-lauroyl ethylester monohydrochloride (LAE; 0, 125, 170, or $200 \mathrm{mg} / \mathrm{L}$ ) and held at $6^{\circ} \mathrm{C}$ for up to $21 \mathrm{~d}$. The horizontal line at $4.3 \mathrm{log}$ cfu/mL represents the Pasteurized Milk Ordinance (PMO) limit of $20,000 \mathrm{cfu} / \mathrm{mL}$ for pasteurized fluid milk. Error bars represent \pm 1 SD from the mean of data collected from 3 independent experiments. ${ }^{\mathrm{a}, \mathrm{b}}$ Different letters within the same graph indicate statistically significant differences in bacterial numbers $(P<0.05)$ by Dunnett's method of statistical analysis on $\log _{10}$-transformed data.

The objective of this study was to determine if addition of LAE to flavored and unflavored fluid milk products at levels currently approved for use in various food products would result in extension of product shelf life relative to that of comparable untreated products. The US Pasteurized Milk Ordinance (FDA, 2007) specifies a bacterial limit of $20,000 \mathrm{cfu} / \mathrm{mL}$ for grade A pasteurized milk while the milk is offered for sale; therefore, for the purpose of our study, "shelf life" was defined as the number of days postpasteurization that a fluid milk product can be held under refrigerated storage $\left(6^{\circ} \mathrm{C}\right)$ before reaching 20,000 cfu of bacteria/mL.

Samples of commercially processed homogenized and pasteurized chocolate and unflavored fluid milk products that had been packaged in paperboard gable-top containers (polyethylene/paperboard/polyethylene) were obtained on processing day on each of 3 independent occasions from the Cornell University Dairy processing facility (Ithaca, NY). For each of the 3 trials, $946 \mathrm{~mL}(1$ quart) of $3.25 \%$ fat unflavored homogenized milk and of $3.25 \%$ fat chocolate milk were obtained. Process temperatures were $79.5^{\circ} \mathrm{C}$ for $23 \mathrm{~s}$ for the unflavored milk and $82^{\circ} \mathrm{C}$ for $23 \mathrm{~s}$ for chocolate milk. Samples were collected and handled according to Standard Methods for the Examination of Dairy Products (SMEDP; Laird et al., 2004). A commercially prepared $10 \%$ LAE solution (Mirenat-N) was obtained from A\&B Ingredients (Fairfield, NJ).

To create subsamples from the same product for testing at $7,14,17$, and $21 \mathrm{~d}$ postprocessing, each milk sample was shaken as described in SMEDP and then the product was distributed aseptically among 4 sterile Pyrex bottles (Corning Inc., Corning, NY) with screw caps. The following treatments were prepared for both the chocolate and unflavored milk samples: a control (no LAE), $100 \mathrm{~mL}$ of milk with $125 \mathrm{mg} / \mathrm{L}$ of LAE, $100 \mathrm{~mL}$ of milk with $170 \mathrm{mg} / \mathrm{L}$ of LAE, and $100 \mathrm{~mL}$ of milk with $200 \mathrm{mg} / \mathrm{L}$ of LAE. As $200 \mathrm{mg} / \mathrm{L}$ of LAE was the upper limit suggested by the manufacturer (A\&B Ingredients), it was chosen as the maximum LAE concentration for this study. The samples were held at $6^{\circ} \mathrm{C}$ and pour plated for bacterial enumeration according to SMEDP (Laird et al., 2004) within $24 \mathrm{~h}$ of processing, and at 7,14,17, and $21 \mathrm{~d}$ postprocessing. Bacterial colonies on the plates were counted after 48 $\mathrm{h}$ of incubation at $32^{\circ} \mathrm{C}$. All standard plate count data were $\log _{10}$-transformed. Dunnett's method of statistical analysis was performed using JMP software (SAS 


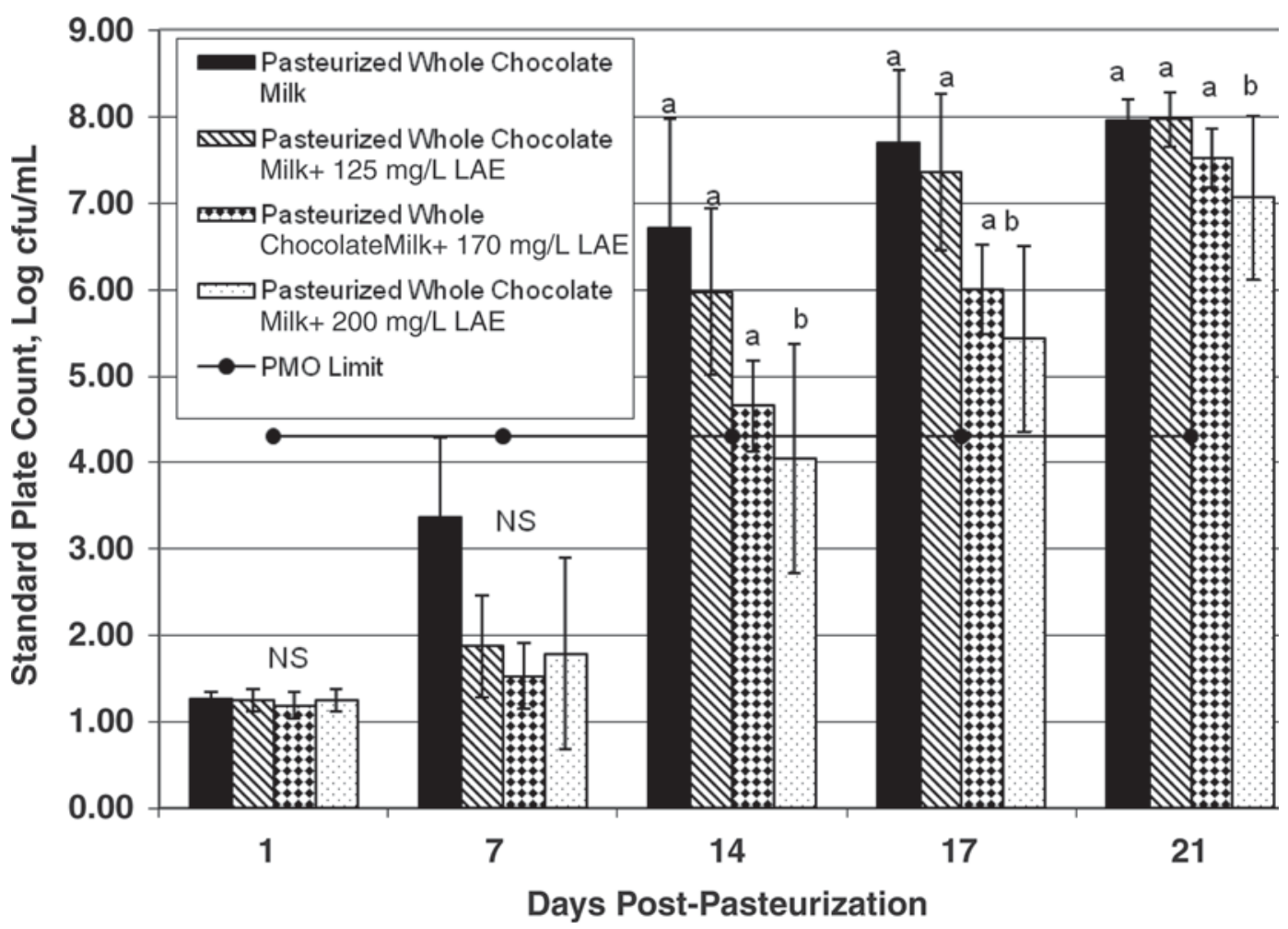

Figure 2. Mean standard plate count for pasteurized chocolate milk treated with L-arginine, No-lauroyl ethylester monohydrochloride (LAE; $0,125,170$, or $200 \mathrm{mg} / \mathrm{L}$ ) and held at $6^{\circ} \mathrm{C}$ for up to $21 \mathrm{~d}$. The horizontal line at $4.3 \mathrm{log} \mathrm{cfu} / \mathrm{mL}$ represents the Pasteurized Milk Ordinance (PMO) limit of $20,000 \mathrm{cfu} / \mathrm{mL}$ for pasteurized fluid milk. Error bars represent $\pm 1 \mathrm{SD}$ from the mean of data collected from 3 independent experiments. ${ }^{\mathrm{a}, \mathrm{b}}$ Different letters within the same graph indicate statistically significant differences in bacterial numbers $(P<0.05$ or $P<0.075$ for $200 \mathrm{mg} / \mathrm{L}$ of LAE on d 14) by Dunnett's method of statistical analysis on $\log _{10}$-transformed data.

Institute, Cary, NC) to compare bacterial counts in the treated samples to those in the control sample in each group.

The effects of different concentrations of LAE on bacterial numbers in unflavored and chocolate milk products were evaluated over a 21-d period (Figures 1 and 2). Overall, our data show that LAE limited bacterial growth and extended the shelf life of unflavored milk. Bacterial counts in the unflavored milk without LAE were $<2 \log \mathrm{cfu} / \mathrm{mL}$ immediately postprocessing and increased to $>7 \mathrm{log} \mathrm{cfu} / \mathrm{mL}$ after $21 \mathrm{~d}$ of storage. In the unflavored milk treated with 125,170 , or $200 \mathrm{mg} / \mathrm{L}$ of LAE, bacterial counts reached 3.64, 2.65, and 1.43 $\log \mathrm{cfu} / \mathrm{mL}$ respectively after $21 \mathrm{~d}$ of storage. Bacterial counts in unflavored milk treated with $200 \mathrm{mg} / \mathrm{L}$ of LAE were $5.77 \log \mathrm{cfu} / \mathrm{mL}$ lower than in untreated milk at $21 \mathrm{~d}$ postprocessing. Bacterial counts in unflavored samples containing 170 and $200 \mathrm{mg} / \mathrm{L}$ of LAE were significantly lower $(P<0.05)$ than those in the untreated milk at $\mathrm{d} 17$ and 21 .

Bacterial counts in chocolate milk without LAE were $<2 \log \mathrm{cfu} / \mathrm{mL}$ immediately after processing, but increased to nearly $8 \log \mathrm{cfu} / \mathrm{mL}$ after $21 \mathrm{~d}$ of storage.
Chocolate milk treated with 125,170 , or $200 \mathrm{mg} / \mathrm{L}$ of LAE had bacterial counts of 7.96, 7.44, and $7.06 \mathrm{log}$ $\mathrm{cfu} / \mathrm{mL}$ respectively, after $21 \mathrm{~d}$ of storage. Bacterial counts in chocolate milk treated with $200 \mathrm{mg} / \mathrm{L}$ of LAE were $0.9 \log \mathrm{cfu} / \mathrm{mL}$ lower than those in the untreated milk at $21 \mathrm{~d}$ postprocessing. Bacterial counts in the chocolate milk samples treated with $200 \mathrm{mg} / \mathrm{L}$ of LAE were significantly lower than in the control samples $(P$ $<0.05$ ) at $\mathrm{d} 17$ and 21 , with a weakly significant difference $(P<0.075)$ between the control and the chocolate sample containing $200 \mathrm{mg} / \mathrm{L}$ of LAE on d 14. There were no significant differences between the samples with 170 and $125 \mathrm{mg} / \mathrm{L}$ of LAE and the controls on any test day $(P>0.05)$.

Higher bacterial numbers in matched samples of chocolate and unflavored milk have been documented previously by Douglas et al. (2000). Specifically, pasteurized chocolate milk had a greater relative increase in bacterial numbers over $21 \mathrm{~d}$ of shelf life when compared with paired pasteurized unflavored milk. The chocolate powder that had been added to the milk was implicated as promoting more rapid microbial growth in the chocolate milk relative to that in the unflavored 
milk. Our results are consistent with the findings from this previous study. In the present study, counts in the chocolate control samples (without LAE) reached $20,000 \mathrm{cfu} / \mathrm{mL}$ between 10 and $14 \mathrm{~d}$ postprocessing, whereas counts in the unflavored control milk reached $20,000 \mathrm{cfu} / \mathrm{mL}$ between 14 and $17 \mathrm{~d}$ postprocessing. The addition of LAE more effectively retarded bacterial growth in unflavored milk than in chocolate milk. It is possible that the reduced effectiveness of LAE in chocolate milk is because of the presence of stabilizers in the chocolate powder (e.g., carrageenan), as the presence of stabilizers has been implicated in decreasing the effectiveness of LAE in retarding bacterial growth (Gil Bakal, A\&B Ingredients, Fairfield, NJ; personal communication).

The cost of adding $200 \mathrm{mg} / \mathrm{L}$ of LAE to fluid milk would be approximately $\$ 0.30$ per gallon of finished product (as of August 2008). Therefore, with the average retail price of a gallon of whole milk at $\$ 3.816$ in 2008 , the addition of LAE would result in at least a $9.6 \%$ increase in retail price. The addition of LAE to milk will also affect the labeling of milk products. According to the USDA (2008a, b), the addition of LAE to fluid milk would require labeling the product as "milk" with the addition of the common name of the ingredient and a statement describing the function of the ingredient, such as "preservative," or "to retard spoilage" rather than simply labeling the product as "milk." Consumer perspectives on this proposed designation would need to be assessed to gauge acceptance of this additive.

The present study did not assess the sensory consequences of LAE addition on product flavor or acceptability. Future testing of the effects of LAE on sensory characteristics of milk will be needed. Although the addition of the antimicrobial LAE to chocolate and unflavored milk was effective in retarding bacterial growth, it was considerably more effective in unflavored milk than in chocolate milk. Our results suggest a possible role for GRAS antimicrobials such as LAE for use in the dairy industry as a way to extend product shelf life.

\section{ACKNOWLEDGMENTS}

This project was supported by the New York State Milk Promotion Advisory Board through the New York
State Department of Agriculture and Markets - NYS dairy farmers committed to production of high quality dairy products. The authors thank the management and employees of the Cornell University Dairy Processing Plant for assistance with this study.

\section{REFERENCES}

Bakal, G., and A. Diaz. 2005. The lowdown on lauric arginate. Food Qual. February/March 2005:54-61.

Carey, N. R., S. C. Murphy, R. N. Zadoks, and K. J. Boor. 2005. Shelf lives of pasteurized fluid milk products in New York State: A tenyear study. Food Prot. Trends 25:102-113.

Douglas, S. A., M. J. Gray, A. D. Crandall, and K. J. Boor. 2000 Characterization of chocolate milk spoilage patterns. J. Food Prot. 63:516-521.

FDA. 2007. Page 28 in Grade "A" Pasteurized Milk Ordinance. US Department of Health and Human Services, Public Health Service, Washington, DC.

IDFA. 2007. Fluid milk sales and consumption. Pages 66-81 in Dairy Facts. International Dairy Foods Association, Washington, DC.

Laird, D. T., A. Gambrel-Lenarz, F. M. Scher, T. E. Graham, and R. Reddy. 2004. Tests for groups of microorganisms. Pages 153-186 in Standard Methods for the Examination of Dairy Products. 17th ed. M. Wehr, ed. Am. Public Health Assoc., Washington, DC.

Luchansky, J. B., J. E. Call, B. Hristova, L. Rumery, L. Yoder, and A. Oser. 2005. Viability of Listeria monocytogenes on commerciallyprepared hams surface treated with acidic calcium sulfate and lauric arginate and stored at $4^{\circ} \mathrm{C}$. Meat Sci. 71:92-99.

Rodriguez, E. J. Seguer, X. Rocabayera, and A. Manresa. 2004 Cellular effects of monohydrochloride of L-arginine, $\mathrm{N}^{\alpha}$-lauroyl ethylester (LAE) on exposure to Salmonella typhimurium and Staphylococcus aureus. J. Appl. Microbiol. 96:903-912.

Ruckman, S. A., X. Rocabayera, J. F. Borzelleca, and C. B. Sandusky. 2004. Toxicological and metabolic investigations of the safety of $\mathrm{N}$ - $\alpha$-lauroyl-L-arginine ethyl ester monohydrochloride (LAE). Food Chem. Toxicol. 42:245-259.

US Census Bureau. 2008. Per capita consumption of selected beverages by type: 1980 to 2005. http://www.census.gov/compendia/statab/ tables/08s0203.pdf Accessed November 24, 2008.

USDA. 2008a. Food labeling. 21CFR part 101. http://edocket.access. gpo.gov/cfr_2009/aprqtr/21cfr101.22.htm

USDA. 2008b. Milk and cream. 21CFR part 131. http://edocket. access.gpo.gov/cfr_2008/aprqtr/21cfr131.3.htm

USDA. 2008c. Safe and suitable ingredients used in the production of meat and poultry products. http://www.fsis.usda.gov/OPPDE/ rdad/FSISDirectives/7120.1Amend15.pdf Accessed October 03, 2008 . 